всеукраїнських (з міжнародною участю) форумах.

Робота 3 найновішими різновидами медичної документації (їх укладанням та оформленням) сприяє закріпленню вивченого мовного матеріалу на практичному рівні функціонування літературної професійної мови.

Запропоновані напрямки викладання i засвоєння змістового наповнення дисципліни є актуальними для роботи в аудиторії (практичні заняття), дистанційного навчання, самостійного опрацювання, створення програм відповідних елективних курсів та свідчать на користь нормативності та обов'язковості навчальної дисципліни «Українська мова (за професійним спрямуванням)» у вищих медичних навчальних закладах. Вони повною мірою реалізують мету курсу: опанувати літературну професійну мову на рівні фахового спілкування, розширити лексичний i термінологічний запас для подальшого його використання у процесі здобування вищої медичної освіти.

\title{
Література
}

1. Мацюк 3. Українська мова професійного спілкування : [навч. посібн]. / Зоряна Мацюк, Ніна Станкевич. - К. : Каравела, 2010. - 352 с. 2. Литвиненко Н. П., Українська медична термінологія у фаховій мові лікаря: [навч. посіб.]/ Н. П. Литвиненко, Н. В. Місник. - К. : Книга-плюс, 2008. - 176 с. 3. Лінгвістичний аналіз тексту: словник термінів / [Голянич М. І., Іванишин Н. Я., Ріжко Р. Л., Стефурак Р. І.] ; за редакцією М. І. Голянич. - Івано-Франківськ : Сімик, 2012. - 392 с. 4. Наказ Міністерства освіти і науки України № 1392 від 25.11.2014 «Про визначенням таким, що втратив чинність, наказ Міністерства освіти і науки України від 09.07.2009 № 642» [Електронний ресурс]. - Режим доступу: http://www.mon. gov.ua/ua/ about-ministry/normative/32360. 5. Про вищу освіту: Закон України від 1 липня 2014 року № 1556-VII // Відомості Верховної Ради України. - 2014. - № 37-38. 6. Фахова мова медика: українська мова за професійним спрямуванням : [навч. посіб.] / Н. П. Литвиненко, Н. В. Місник. - К. : Книга-плюс, 2012. - 333 с. 7. Шевчук С. В. Українська мова за професійним спрямуванням : [підручник].С. В. Шевчук, І. В. Клименко. - [3-тє вид., виправ. і доповнен.] - К. : Алерта, 2013. $696 \mathrm{c}$.

УДК 378.147

Наталія Соловйова, Ніна Ігнатюк

\section{РОЗВИТОК УНІВЕРСАЛЬНИХ УМІНЬ У ПРОЦЕСІ ЧИТАННЯ ІНШОМОВНИХ ТЕКСТІВ}

Соловйова Н. Д., Ігнатюк Н. А. Розвиток універсальних умінь у процесі читання іншомовних текстів.

У статті пропонуються можливі шляхи для підготовки випускників вишів задля подальшої самоосвіти. Розглянуто необхідність формування універсальних умінь студентів на основі використання технології розвитку критичного мислення, наведено приклади застосування графічних організаторів у процесі читання текстів іноземною мовою.

Ключові слова: універсальні вміння, критичне мислення, саморозвиток особистості, графічні організатори, читання.

Соловьева Н. Д. Игнатюк Н. А. Развитие универсальных умений в процессе чтения иноязычных текстов.

В статье предлагаются возможные пути подготовки выпускников вузов к 
дальнейшему самообразованию. Рассмотрена необходимость формирования универсальных умений студентов на основе использования технологии развития критического мышления, приведены примеры применения графических организаторов в процессе чтения текстов на иностранном языке.

Ключевые слова: универсальные умения, критическое мышление, саморазвитие личности, графические организаторы, чтение.

Soloviova N. D., Ihnatiuk N. A. Development of universal skills while reading the texts in a foreign language

The article suggests possible ways to prepare graduates to further self-education. The need to develop universal skills of students on the basis of development of critical thinking skills is considered, examples of graphic organizers when reading texts in a foreign language are given.

Key words: universal skills, critical thinking skills, self-development of individuality, graphic organizers, reading.

Одним із головних критеріїв професійної перспективності вчителя $є$ його готовність до безперервної освіти і, особливо, до самоосвіти. Викладачі педагогічних навчальних закладів добре розуміють, що їх випускники розпочинають учительську роботу в молодому віці, не маючи достатнього життєвого й педагогічного досвіду і не володіючи значним обсягом науково-методичних знань. Уже у стінах вищого навчального закладу у студентів повинні бути сформовані ті вміння, необхідні випускнику для переходу на самоосвіту і які допомагатимуть йому вчитися протягом усього життя, тому викладачі повинні піклуватися про створення відповідних умов задля формування таких умінь.

На сучасному етапі для того, щоб успішно соціалізуватися в суспільстві, що швидко змінюється, недостатньо володіти лише предметними знаннями. Завдання викладача - не просто передати студенту сукупність знань, а навчити його вчитися, мислити, оскільки лише володіння універсальними прийомами навчальної діяльності може стати запорукою його професійного успіху. Необхідно формувати у студентів універсальні вміння, тобто необхідні надпредметні (метапредметні) вміння. Універсальні вміння розвиваються в учнів на базі одного або кількох навчальних предметів і стають способами діяльності, що застосовуються як в освітньому процесі, так і у розв'язанні реальних життєвих проблем. Надпредметний (метапредметний) характер універсальних навчальних дій забезпечує загальнокультурний, особистісний i пізнавальний розвиток та саморозвиток особистості, а також наступність усіх ступенів освітнього процесу. Розуміння того, що в основі успішності, результативності та самостійності навчання лежать загальні навчальні дії, що мають пріоритетне значення стосовно вузько предметних знань і вмінь, визнається нині усіма провідними психологами і дидактами, такими як: А. Асмолов, С. Воровщиков, П. Гальперин, М. Гінзбург, Н. Громико, Н. Гуткіна, В. Давидов, О. Зак, Т. Нежнова, К. Поливанова, Д. Ельконін, А. Хуторський та ін. Попри довгу історію поняття, донині немає єдиного його тлумачення і різні наукові школи трактують його порізному. Зокрема, А. Асмолов визначає «універсальні навчальні дії» як сукупність способів дії учня (а також навичок навчальної роботи, що пов'язані з ними), які забезпечують його здатність до самостійного засвоєння нових знань i вмінь, включаючи організацію цього процесу, тобто здатність суб'єкта до саморозвитку та самовдосконалення шляхом свідомого й активного засвоєння й подальшої інтеріоризації нового соціального досвіду [1, с. 3]. 
Незважаючи на визнання педагогічною наукою $\mathrm{i}$ практикою значення метапредметних (універсальних) дій та вмінь для успішного навчання, дотепер не проводиться серйозна систематична робота 3 їх упровадження у процес навчання у вищих навчальних закладах. Стихійність розвитку універсальних навчальних дій знаходить відображення у низькій допитливості й ініціативі частки студентів, у труднощах самовільної регуляції навчальної діяльності та низькому рівні логічних дій.

Сучасні дослідження свідчать, що лише $25 \%$ студентів-першокурсників володіють навичками, які необхідні для логічного й абстрактного мислення - такого типу мислення, який потрібен, наприклад, для відповіді на питання: «Що трапиться, якщо...» та для оцінки абстрактних ідей [9]. Наукові дослідження провідних вітчизняних та зарубіжних науковців надають можливість розробити шляхи формування метапредметних умінь засобами навчальних предметів з урахуванням специфіки організації навчального процесу.

Метою статmі є розглянути можливості формування метапредметних умінь під час роботи з іншомовним текстом.

Багаторічний досвід роботи зі студентами 1-2 курсів показує, що у процесі читання текстів у студентів виникають труднощі у формулюванні простих оцінних суджень на основі тексту, в обгрунтуванні висловленого судження, при пошуку прикладів,що пояснюють зміст незнайомих слів, у перетворенні інформації одного виду на інший, наприклад, складання таблиць на основі тексту, труднощі під час роботи 3 малюнком, таблицею, діаграмою або схемою. Усе це свідчить про недостатній рівень розвитку універсальних умінь у студентів. Формування універсальних навчальних дій повинно стати цілеспрямованим.

Розвиток універсальних умінь у навчальному процесі можливий при використанні освітніх технологій, однією з яких $є$ технологія розвитку критичного мислення. Критичне мислення при цьому розуміється так:

- по-перше, критичне мислення є мислення самостійне;

- по-друге, інформація $є$ відправним, а не кінцевим пунктом критичного мислення, оскільки щоби дійти певної думки, потрібно опрацювати безліч фактів, ідей, текстів, тобто інформації;

- по-третє, критичне мислення починається 3 постановки питань і усвідомлення проблем, які потрібно розв'язати;

- по-четверте, критичне мислення прагне до переконливої аргументації; критично мисляча людина знаходить власне розв'язання проблеми і підкріплює це рішення розумними, обгрунтованими аргументами;

- по-п'яте, критичне мислення є мислення соціальне; усяка думка перевіряється тоді, коли нею діляться 3 іншими, тому так важливі якості, що необхідні для продуктивного обміну думками - терпимість, уміння слухати інших, відповідальність за власну позицію [4]. Вищезгадані якості повинні бути властиві й сучасній молодій людині, яка розпочинає свій життєвий шлях.

Необхідно зазначити, що нині у спеціальній літературі наведений достатньо широкий арсенал методичних прийомів та технологій, спрямованих на розвиток критичного мислення. Критичне мислення формується, перш за все, в дискусії, письмових роботах та активній роботі з текстами.

Критичний стиль мислення може бути сформовано, поряд 3 іншими дисциплінами, і на базі іноземної мови, зокрема під час роботи 3 іншомовними текстами. Викладач іноземної мови, що працює в рамках технології критичного 
мислення, має добре усвідомлювати важливість вибору прийомів роботи з текстами. Необхідно зазначити, що у процесі розвитку критичного мислення широко використовуються графічні організатори.

Результати дослідження ефективності використання графічних/візуальних організаторів у різних предметних галузях широко представлені в зарубіжних виданнях. В огляді, підготовленому Е. Холл і Н. Стренгман із Національного центру експертної оцінки загальноосвітніх програм (США), відмічається позитивний вплив використання графічних організаторів на формування надпредметних умінь, що лежать в основі розвитку компетенцій [10]. У вітчизняній літературі, присвяченій активним методам навчання, їх опис $\epsilon$ фрагментарним. Першою i найбільш розробленою ділянкою застосування графічних організаторів $є$ читання і письмо.

Під графічним організатором розуміється візуальна або графічна демонстрація відношень між фактами, термінами, поняттями або ідеями згідно 3 конкретним навчальним завданням. Іноді графічні організатори називають понятійними картами, когнітивними організаторами, концептуальними діаграмами і т.п. [5, с. 56]. Графічне представлення різних розумових процесів створює на плоскості об'єктивну форму цих розумових процесів, дозволяючи учням і вчителям створювати альтернативні структури, опрацьовувати зміст, актуалізувати відоме, вплітати досвід і знання в нову інформацію, виправляти помилки [7]. Графічні організатори є різновидами наочності, яка стимулює процес мислення. Методи візуалізації організують і спрямовують розумовий процес, дозволяючи зрозуміти тему або проблему учням із різним рівнем знань і здібностей. Доведено, що візуальні організатори, до яких належать графічні організатори:

- активізують розуміння учнів;

- сприяють мисленню вищого рівня;

- особливо актуальні для невстигаючих учнів, які ще не виробили методи ефективного навчання і стратегію мислення (Mayer, 1989; McKeachie, 1984) [6].

Ми поділяємо думку О. Сиземиної, що використання графічних організаторів у роботі з навчальним текстом дозволяє:

- виявити рівень володіння темою;

- актуалізувати наявні лексичні знання, життєвий досвід, емоційну сферу студентів;

- задіяти всі когнітивні процеси студентів;

- розвивати логіку й асоціативне мислення;

- краще орієнтуватися у темі за рахунок виокремлення ключових моментів та опорних пунктів;

- генерувати пошук оригінальних ідей, розвивати творчі здібності i, отже, сприяти підвищенню мотивації;

- викликати інтерес до власних роздумів і самоаналізу;

- наочно представити власні розумові процеси та їх результати, що сприяє упорядкуванню, структуруванню та редактуванню сформованих і висловлених думок;

- забезпечити негайний зворотній зв'язок [8].

Види графічних організаторів $є$ різноманітними. Вони розрізняються за завданнями і за організацією навчального процесу. Наявні графічні організатори для збирання інформації; послідовностей; систематизації й структурування понять/ ідей/ уявлень або когнітивні графічні організатори; категоризації/ класифікації; відношень; оцінки; розв'язання проблем/ вибору кращого рішення/ підготовки проекту; структурування тексту; підготовки творчого письмового завдання тощо [5]. 
До графічних організаторів можна віднести схеми, діаграми i таблиці. Найпоширеніші графічні організатори - це кластер/ карта думки, таблиця «Так-Ні», діаграма Вена, дискусійна сітка та інші. Мета та кінцевий результат таких прийомів формування метапредметних умінь. 3 їх допомогою для студентів створюються умови оцінювати й коректувати процес своєї навчальної діяльності, орієнтуватися в ситуації та обмірковувати можливі відповіді на різні питання. Графічні організатори спонукають осмислювати інформацію та пояснювати свій вибір під час розв'язання проблеми, а також порівняти своє рішення з іншими; допомагають учням керувати інтелектуальними процесами, які пов'язані з академічним навчанням. Окрім того, організатори дозволяють учителям привчати учнів до мислення вищого рівня, не нівелюючи предметне навчання. Учителі-предметники можуть використовувати візуальні організатори у класі для того, щоби чітко з'ясувати цілі та розумові процеси, а це, в свою чергу, наповнює навчання змістом. Мислення можна втілити в багатьох формах, а візуальні організатори допомагають їх створити [3], вони упорядковують i організують мислення.

Структура технології розвитку критичного мислення розроблена американськими педагогами Дж. Стіл, К. Мередитом і Ч. Темплом [6]. Услід за американськими колегами російські педагоги та дослідники С. Заїр-Бек і I. Муштавинська подали освітню технологію розвитку критичного мислення у вигляді таких етапів [2, с. 11-14]:

- виклик (спонукання);

- осмислення (реалізація);

- рефлексія (міркування).

Цілі зазначених етапів співвідносяться з цілями роботи над текстом, які прийняті в методиці навчання читанню. Робота над текстом для читання передбачає всі три етапи розвитку критичного мислення. Так, виклик (спонукання) співвідноситься 3 дотекстовим етапом (pre-reading), осмислення (реалізація) відповідає текстовому етапу (while-reading), рефлексія (міркування) відповідає цілям післятекстового етапу (post-reading). Вибір графічних організаторів безпосередньо залежить від етапу роботи над текстом.

I. Pre-reading (виклик) - коротке узагальнення наявних знань; на цьому етапі висуваються припущення, формулюються питання, на які бажано отримати відповіді. На стадії виклику учні будують прогнози, створюють своє бачення предмета, що вивчається, або поняття, оперують сформованими в пам'яті уявленнями, ознаками та перетворюють їх. Робота проводиться індивідуально, в парах або групах.

На аналізованому етапі роботи $з$ текстом можуть бути використані такі графічні організатори:

1. «Понятійне колесо». Свою назву цей прийом отримав тому, що у кінцевому вигляді дійсно нагадує колесо, у центрі якого пишеться ключове слово (поняття/тема/проблема для даного уроку), а навколо нього - з'єднані променями слова-асоціації (словосполучення), які пропонуються учнями.

2. «Складання кластера». Зміст цього прийому полягає у спробі систематизувати наявні знання 3 тієї чи іншої проблеми. Складання «кластера» дозволяє учням вільно й відкрито думати з приводу будь-якої теми. Учень записує у центрі листка ключове поняття, а від нього малює стрілки - промені в різні боки, які поєднують це слово з іншими, від яких, у свою чергу, промені розходяться далі й далі, вказуючи на змістові поля того чи іншого поняття. Це спосіб графічної організації матеріалу, що дозволяє зробити наочними ті розумові процеси, які відбуваються при зануренні у певну тему. Іноді такий спосіб називають «наочним мозковим штурмом». 
3. «Вступне питання» («ВП»). «ВП» називають питанням високого рівня, який вимагає розумових зусиль під час відповіді та допомагає налаштувати учня на активну роботу протягом усього заняття. Його обговорення повинно тривати не більше 5 хвилин на початку заняття. Наприкінці уроку вчитель і учні повертаються до відповідей, які звучали на початку уроку, щоби підтвердити чи спростувати їх.

\begin{tabular}{|l|l|}
\hline Питання для введення нової теми & Гіпотеза з питання \\
\hline & \\
& \\
\hline
\end{tabular}

4. Передбачення (за фрагментом тексту припустити його тему).

\begin{tabular}{|l|l|}
\hline Фрагмент тексту & Можлива тема \\
\hline & \\
& \\
\hline
\end{tabular}

5. Стратегія KWL (знаємо, бажаємо дізнатися, дізнались).

\begin{tabular}{|l|l|l|}
\hline Знаємо & Бажаємо дізнатися & Дізнались \\
\hline & & \\
& & \\
\hline
\end{tabular}

Перша і друга частини таблиці заповнюються перед читанням. Після отримання інформації заповнюється третя частина таблиці.

II. While-reading (осмислення) - вдумлива робота з новою інформацією (читання тексту). Етап роботи 3 інформацією розвиває вміння бачити проблеми, висувати гіпотези, задавати питання, виокремлювати головне і формулювати його у вигляді тезисів, складати схему по тексту, робити висновки, давати назву тексту, складно й послідовно викладати свої думки, визначати поняття і робити висновки.

Сприйняття інформації (читання) відбувається 3 використанням активних методів читання. Такі методи потребують від учня не звичного пасивного читання, а активного й уважного. Вони зобов'язують не просто читати, а вчитуватися у текст, відстежувати власне розуміння у процесі читання. Робота проводиться індивідуально або в парах.

На аналізованому етапі можливо використовувати такі активні методи сприйняття змісту: технологія «інсерт/ insert», читання 3 зупинками, подвійний щоденник, «товсті» і «тонкі» питання, таблиця «Хто? Що? Де? Коли? Чому?», пошук відповідей на питання, поставлені в першій частині заняття та ін.

1. Під час застосування технології «інсерт/insert» [Vaughan, Estes, 1986] відбувається маркування сприйняття тексту поряд з усвідомленням інформації 3 використанням позначок: V (вже знав); + (нове); - (думав/ю інакше); ! (здивувало); ? (не зрозумів, є питання, бажання дізнатися більше) на полях тексту. На основі цих позначок складаються таблиці.

2. Читання 3 зупинками (припустіть, що буде далі?). Викладач ознайомлює студентів з новим текстом, але після прочитання частини тексту питає: А що далі? Студенти складають прогноз, висуваючи свої гіпотези. Потім читання продовжується i студенти визначають чий прогноз справдився. Такий прийом розвиває мислення, вміння висувати гіпотези і виховує уважного слухача.

3. Подвійний щоденник (цитата плюс міркування).

\begin{tabular}{|l|l|}
\hline Цитата & Коментар \\
\hline & \\
\hline
\end{tabular}


4. «Товсті» (проблемні) i «Тонкі» (конкретні) запитання.

\begin{tabular}{|l|l|}
\hline «Тонкі» запитання & «Товсті» запитання \\
\hline Хто...? & Дайте три пояснення, чому... \\
Що...? & Поясніть, чому... \\
Коли...? & Чому ви так думаєте...? \\
Може...? & Чому ви вважаєте...? \\
Буде...? & У чому різниця...? \\
Як звали...? & Що, коли (якщо)...?
\end{tabular}

5. Таблиця «Хто? Що? Де? Коли? Чому?» заповнюється на стадії осмислення під час роботи 3 інформацією і використовується для початкової систематизації інформації тексту. Відповідь на кожне питання фіксується у відповідній графі таблиці.

\begin{tabular}{|c|c|c|c|c|}
\hline Who? & What? & Where? & When? & Why? \\
\hline & & & & \\
\hline
\end{tabular}

III. Post-reading (рефлексія) - інтеграція нових і наявних знань. На даному етапі активність спрямована на:

- звернення учнів до початкових нотаток-міркувань;

- внесення змін, доповнень;

- встановлення причинно-наслідкових зв'язків між блоками інформації;

- звернення до ключових слів, правильним і неправильним твердженням;

- відповіді на поставлені питання;

- написання творчих робіт.

На стадії рефлексії відбувається аналіз, творча перероблення та інтерпретація вивченої інформації. Робота проводиться індивідуально, в парах або групах. Відбувається графічна систематизація матеріалу у вигляді таблиць, кластерів тощо.

\section{1. «Маркувальна таблиця».}

Завершивши читати, учні заповнюють маркувальну таблицю, у кожний стовпчик якої слід внести не менше 3-4 пунктів. Поряд з реченнями пропонується поставити значки: + правда, - неправда, ? не впевнений.

\section{2. Т-таблиця.}

Таблиця використовується для фіксації протилежних думок 3 конкретного питання. Це універсальний графічний організатор порівняльних подвійних даних (так/ні, за/проти), особливо зручний для відтворення контрастних, суперечливих відомостей, що відрізняються за певними критеріями.

\begin{tabular}{|c|c|}
\hline \multicolumn{2}{|c|}{ Аргументи } \\
\hline за & проти \\
\hline & \\
\hline
\end{tabular}

\section{3. Піраміда оповідання (Story pyramid).}

Це завдання, окрім знання змісту прочитаного, потребує уміння мислити раціонально.

Line 1. Name of the main character. (Ім'я головного героя).

Line 2. Two words describing g the main character. (Два слова, які описують головного героя).

Line 3. Three words describing the setting. (Три слова, що описують навколишнє середовище). 
Line 4. Four words stating the problem. (Чотири слова, що визначають проблему).

Line 5. Five words describing one main event. (П'ять слів, які описують головну подію). подію).

Line 6. Six words describing the second event. (Шість слів, які описують другу

Line 7. Seven words describing the third event. (Сім слів, що описують третю подію).

Line 8. Eight words stating the solution of the problem. (Вісім слів, які вказують на розв'язання проблеми).

4. Питання для розв'язання проблеми.

1. Яку головну проблему необхідно розв'язати?

2. Яка інформація у вас $\epsilon$ ?

3. Що іще вам відомо, що допомогло б розв'язати проблему? Що ще потрібно знати?

4. Які три головних способи розв'язання проблеми? Який з обраних способів найкращий і чому?

\section{5. Прийом «Фішбоун» (риб'ячий кістяк).}

Такий прийом дозволяє виявити причинно-наслідкові зв'язки теми, факту чи події, що вивчаються. Схема фішбоуна зображає риб'ячу кістку, в голові якої записується проблемне питання теми, по кісточкам із боків навпроти одна одної причини й наслідки (або причини та конкретні факти, підтверджуючі їх наявність), у хвості - сформульований висновок.

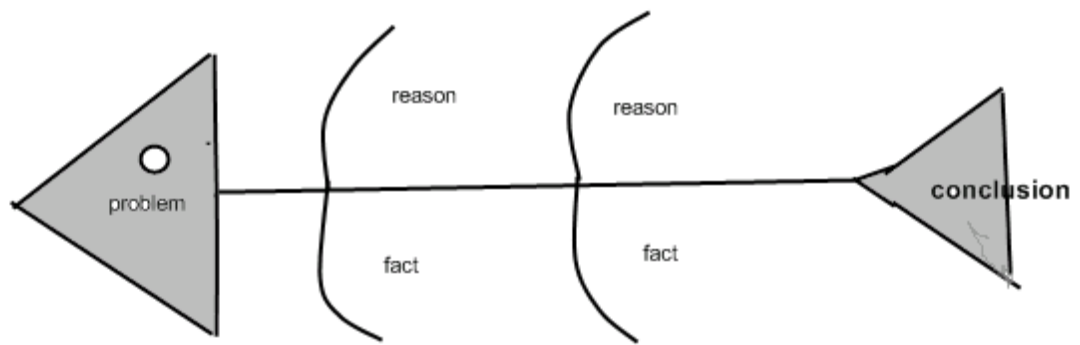

Показавши зразок, необхідно долучити учнів до пошуку власного графічного організатора. Наприклад, розширити пропоноване завдання й оформити його в такому вигляді:

Problems $\rightarrow$ consequences $\rightarrow$ solutions

\section{6. Концептуальна таблиця.}

Концептуальна таблиця належить, як і кластери, до графічних організаторів, які наочно відтворюють розумові процеси порівняння, зіставлення тощо. У концептуальній таблиці вертикально розташовується те, що підлягає порівнянню, а горизонтально - різні характеристики, за якими відбувається порівняння. Учні у групах заповнюють концептуальну таблицю, яка складається із двох (трьох) стовпчиків: (+) - інформація, що характеризує той чи інший об'єкт позитивно, (-) негативні ознаки об'єкта, що вивчається. У концептуальній таблиці компактно «упакований» значний обсяг аналітичної інформації. Така таблиця є коректною задля подальшого обговорення усією групою та вироблення оптимального варіанту 3 конкретної проблеми. 
7. «SWOT-аналіз». У сучасних гуманітарних науках, особливо в педагогіці, «SWOT-аналіз» використовується як технологія, що дозволяє диференціювати чинники і наслідки за принципом 4 категорій:

$\mathrm{S}$ - Strengths (сильні сторони, плюси, переваги)

W - Weaknesses (слабкі сторони, негативні ознаки)

O - Opportunities (можливості, потенційні напрямки)

T - Threats (загрози, негативні наслідки).

8. Таблиця «Плюс-Мінус-Цікаво» (ПМЦ).

Таблиця ПМЦ, створена Едвардом де Боно, використовується для аналізу фактів та явищ 3 позиції позитивних сторін (П), негативних (М) i перспективних, що викликали зацікавленість (Ц). Такий прийом дозволяє оцінити будь-яку подію, явище чи захід об'єктивно та неупереджено, виявити переваги й недоліки, обгрунтувати перспективи розвитку, сформулювати логічно правильне висловлювання, беручи до уваги різні позиції. Аналіз завершується висновком.

\section{9. Таблиця «Аргумент/контраргумент».}

Така таблиця використовується для розгляду позитивних і негативних боків явища, а також для побудови власної аргументації під час аналізу двох протилежних поглядів на проблему.

Отже, використання графічних організаторів на всіх етапах роботи 3 текстом розвиває:

- уміння бачити проблеми;

- уміння ставити питання;

- уміння висувати гіпотези;

- уміння давати визначення поняттям;

- уміння класифікувати;

- уміння спостерігати;

- уміння робити висновки;

- уміння структурувати матеріал;

- уміння пояснювати, доводити та захищати свої ідеї.

Вищезазначені вміння співвідносяться 3 універсальними вміннями. Читання текстів із використанням графічних організаторів можна розглядати як механізм, що формує самостійність мислення і як засіб розвитку універсальних умінь, які необхідні випускникам вищих навчальних закладів, щоб у подальшому самостійно покращувати свою кваліфікацію та бути успішним у світі, що постійно змінюється.

\section{Література}

1. Асмолов А. Г. Программа развития универсальных учебных действий: структура, содержание, ожидаемые результаты / А. Г. Асмолов. - [Электронный peсурс]. - Режим доступа: http://xn--1504-43dr3agc1bl3t.xn--p1ai/wp-content/uploads01 2. Заир-Бек С. И. Развитие критического мышления на уроке / С. Заир-Бек, И. Муштавинская. - М. : Просвещение, 2004. - 175 с. 3. Кларк Дж. Г. Использование визуальных организаторов для фокусирования на мышлении / Дж. Г. Кларк ; пер. с англ. Е. Н. Волков, 2009. - Электронный ресурс]. - Режим доступа: http://evolkov.net/mapping/index.html. 4. Клустер Д. Что такое критическое мышление?/Д. Клустер // Критическое мышление и новые виды грамотности: [сборник ] / составитель О. Варшавер. - М. : ЦГЛ, 2005. - С. 5-13. 5. Левина Л. М. Организация самостоятельной работы студентов в условиях перехода на двухуровневую систему высшего профессионального образования: [методическое пособие для преподавателей вузов] / Людмила Михайловна Левина. - Н. Новгород : 
Нижегородский государственный университет им. Н.И. Лобачевского, 2010. - 96 с. [Электронный peсурс]. - Режим доступа: http:/www.unn.ru/books/met_files/ LevinaLM.pdf. 6. Основы критического мышления: междисциплинарная программа /Дж. Стил, К. Мередит, Ч. Темпл, С. Уолтер. Пособие 1. - М. : Изд -во «ИОО», 1997. - 213 с. 7. Развитие критического мышления средствами ИКТ. [Электронный pecypc]. - Режим доступа: https://sites.google.com/site/mkiktkm/ vizualnye-organizatory. 8. Сиземина А. Е. Стратегия применения графических организаторов при обучении лексической стороне иноязычной речи / Александра Евгеньевна Сиземина. - [Електронний ресурс]. - Режим доступу: http://vernadsky.tstu.ru/pdf/2009/06/rus_07_2009_06.pdf 9. Халперн Д. Психологія критичного мислення / Дайана Халперн. - [Електронний ресурс]. - Режим доступу: http://lib.rus.ec/b/214789/read. 10. Hall T. (2002). Graphic organizers. Wakefield, MA: National Center on Accessing the General Curriculum./ T. Hall, N. Strangman.[Електронний ресурс].- Режим доступу: http://aim.cast.org/learn/historyarchive/backg roundpapers/graphic_organi.

УДК 378.147

Артем Сушенцев

\section{РЕАЛІЗАЦІЯ ПРИНЦИПІВ ПРОФЕСІЙНОГО ВДОСКОНАЛЕННЯ ВИРОБНИЧОГО ПЕРСОНАЛУ В УКРАЇНІ}

Сушенцев А. О. Реалізація принципів професійного вдосконалення виробничого персоналу в Україні.

У статті досліджені принципи професійного вдосконалення 3 точки зору провідних науковців. Проаналізовані такі принципи професійного вдосконалення виробничого персоналу, як: політехнічний принцип, принцип моделювання професійної діяльності в навчальному процесі, принцип професійної мобільності, принцип модульності тощо.

Ключові слова: принцип навчання, партисипативність, синергія, безперервне професійне навчання, вдосконалення персоналу.

Сушенцев А. А. Реализация принципов профессионального совершенствования производственного персонала в Украине.

В статье исследованы принципы профессионального совершенствования с точки зрения ведущих ученых. Проанализированы такие принципы производственного персонала, как: политехнический принцип, принцип моделирования профессиональной деятельности в процессе обучения, принцип профессиональной мобильности, принцип модульности и т.д.

Ключевые слова: принцип обучения, партисипативность, синергия, непрерывное профессиональное обучение, совершенствование персонала.

Sushentzev A. O. Implementation of the principles of professional development of production personnel in Ukraine.

In the article the principles of professional development in terms of leading scientists are carried out. The principles of the production staff such as: polytechnic principle, the principle of modeling professional activities in the learning process, the principle of the professional mobility, the principle of modularity etc. are analyzed.

Key words: the principle of learning, participatory, synergy, continuous professional training, improvement of personnel. 